\title{
Approaches To The Assessment Of Science Process Skills: A Reconceptualist View And Option
}

K. O. Oloruntegbe, University of Malya, Malaysia

\begin{abstract}
Assessment means many things to many people. There is a plethora of terms and definitions. To measure science-learning outcomes at skills level, assessment was modified and restructured not only in form and context, but in vocabularies and nomenclatures. Thu, there emerged different forms, like alternative, authentic and performance assessments, which are labeled the most suitable for assessing science process skills demonstrated and developed by students during science activities. The author of this paper took a critical look at these various forms and found them not being strong and precise enough for that purpose. What is demanded from the students and teachers in the various forms of assessments differs not much from those of the conventional paper-and-pencil types. Or, at best, it is the product of investigation written on paper and marked by conference examiners. The disadvantages of this conventional practice are much. The author is therefore advocating on-the-spot assessment of skills as complements and supplements to these others. The advantages are overwhelming and are stated in the body of the paper.
\end{abstract}

Keywords: Science process skills, Traditional, Authentic, and On-the-Spot Assessment

\section{INTRODUCTION}

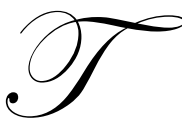

he term assessment presents different perceptions and conceptions. To authors, scholars and curricularissts, there is a plethora of terms and definitions (Butler 1997, Lake, Harmes, Guill and Crist 1998); to the teachers and the learners, it is a hot issue (Oguntonade 1997) and to the general public, it is desirable as well as detestable. The many vocabularies or terms used include: alternative assessment, authentic assessment, performance assessment, traditional or conventional type, naturalistic assessment, process assessment, product process assessment, benchmark, criteria, documentation, graphic organizer, indicators, outcome, portfolio, rubric, standard, etc (Lake et al 1998).

The term assessment itself is derived from a Latin word meaning, "to sit beside, assist in the office of a judge". In history, it was applied and involved in apprenticeship, just as H. Geiger and E. Marsden were apprenticed to E. Rutherford or Apostle Paul to Gamaliel, (Acts 22:3). And even now, it is applicable among the artisansautomobile repairers and has extended to the normal school settings and practices:

Assessment, particularly in traditional type (the first known one), is grounded in educational philosophy that adopts the following reasoning and practice:

- $\quad$ the goal or mission of the school; e.g., maybe to produce productive citizens

- $\quad$ To be a productive citizen, an individual must possess a certain body of knowledge and skills.

- $\quad$ The school must teach the body of knowledge and skills.

- The school must also test students to see if the goal is accomplished; if the students had acquired the knowledge and skills (Mueller 2006). 
It is also driven by school curriculum developed, implemented, and assessed, to determine the acquisition of the learning outcome based on the curriculum package. Assessment can be described as an offshoot of Tyler rationale and Tylerian (Goals-Oriented/Objectives-Based) evaluation model (Tyler, 1949) summed up generally as 'means and end' affair.

Some of these terms, except in the mind of heavy-duty researchers, overlap. Alternative, authentic and performance are used interchangeably to mean the same thing. Traditional test means paper and pencil test - the multiple objectives and essay type also describe as "proxy items" (Grants 1990, Oloruntegbe and Omoifo 2000).

The characterization and categorization assessment fall into a continuum.

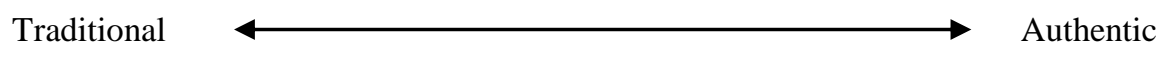

Events at the two ends of the continuum range from selection of response to performing a task; from contrived to real life, from recall or recognition to construction and application, from teachers-structured to learners structured; and from indirect evidence to direct evidence (Grants 1990 and Mueller 2006). Within the continuum lie four categories: 1) tests, 2) product or project assessment, 3) performance assessment, and 4) process skills assessment (CES National 2002). These are, in turn, comprised of many other forms as noted by Lake, et al (1998). All types are useful, however, each has limitations. Therefore, maintaining a balance becomes of utmost importance.

Assessment data is generally of two types - qualitative and quantitative - which are respectively based on, or derived from, detailed description of situation of performance and using values from an instrument-based standardized system. The formal can be more subjective, but can also be much more valuable in the hands of experienced teachers.

Assessment has been found to serve useful purposes to a number of people, including learners, teachers, administrators and, employers (Lake et al 1998, Oloruntegbe 2000, Wiggins 2005). For learners, it provides efficient learning by focusing the student's attention on what is important. It promotes retention and transfer of learning, promotes self-evaluation and self monitoring by the use of well-defined expectations and criteria, motivates learning by communicating progress concerning what a student knows or is able to do, and it shows evidence of work that can be used to get a job, scholarships, and entrance to the next stage of schooling. For the teachers, it provides formative and summative data about student learning and attainment, specifically competency gain, provides diagnostic data to improve learning, assists instructional planning by providing informed feedback, helps to determine effectiveness of approaches and methods, entails program accountability, and it is a tool to communicate to others.

Allocation of resources, decision-making in terms of recruitment of employee and professional development needs are the interest areas of administrators. The employers also need data about what a prospective employee knows and is able to do, as well as evidence that the employee possesses the requisite skills and competence.

Everyone has an interest in conducting an assessment. As an integral part of instruction at all levels of the educational system, assessment answers questions, such as:

- $\quad$ Are we doing what we think we are doing?

- $\quad$ How can we do it better? (Crist et al 1998)

- When do we do it?

More focused questions can be raised, such as:

- $\quad$ Are teachers truly measuring students' capabilities in all areas of cognitive, psychomotor and effective?

- $\quad$ Are teachers not measuring capabilities in the cognitive areas when they mean to measure skills?

- $\quad$ Are teachers employing the right instrument in assessing? 
- Is the evaluation information that is provided on school graduates to the general public and employers reliable?

- Why are employers and institutions of learning home and abroad getting increasingly skeptical of Nigerian school products?

- Why are there prevalence of malpractices and irregularities in private and public examinations or internal and external examinations?

Answers to some of these questions are provided later in this paper. In the meantime, we can say that the questions are predicated upon the validity, reliability, practicality, and usability of assessment types. One can now see why assessment does not only mean many things to different people; it is also a trouble shooter. Many need and use it, a few love it, and some others hate it.

\section{SCIENCE PROCESS SKILLS}

Many scholars have written about process skills. Among these, the view articulated by Gagne has been the most influential. In his theory of learning structure - learning hierarchy and learning prerequisite - Gagne (1965) submitted that the prerequisite knowledge for the concepts and principles in the hierarchy could be obtained only if the students have acquired certain underlying capabilities. These capabilities he called intellectual skills or science processes which, according to Gagne (Gagne, 1965), are needed by students to practice and understand science.

Science A Process Approach, the Gagne-influenced American Association for the Advancement of Science's (AAAS) curriculum, identified 16 of such skills that the curriculum aimed at developing in students exposed to it. This was done through a national survey conducted by the association on what activities the scientists engage in while at work. The Nigerian Educational Research Council, NERC (now the Nigerian Educational Research and Development Council, NERDC) at a conference in Ibadan, Nigeria in 1971 modified these processes to 15 . The 15 process skills are observing, raising questions, communicating, counting number relations, measuring, hypothesizing, experimenting, isolating and manipulating variables, predicting, inferring, interpreting, drawing conclusion, building mental models, making operational definitions and classifying.

Several categorizations have also evolved (Berger, 1982, Nwosu, 1986; Nwosu, 1994; and Ogunleye, 19960). The categorization by Berger (1982) consists of four levels. Statements at each of the levels contain action verbs that can be used in formulating observable and measurable behavioral objectives. By action verbs, I meant the performance tasks. Take, for example, the behavioral objective stated as, "By the end of the lesson, students should be able to separate mixtures of substances and identify the residues and the filterates." 'Separate' and 'identify' are the action verbs in the given behavioral objective.

Of the science learning outcomes - formulation of concepts, development of skills and appropriate scientific attitudes, the cognitive area seems to attract more attention in school teaching, learning and assessment. Teachers seldom teach and assess skills and attitudes (Oloruntegbe, 2000 and Oloruntegbe \& Omoifo, 2000). Educators, policy makers and parents are beginning to recognize that minimums and basics are no longer sufficient (Winking \& Bond 1995) and are calling for a closer match between the skills that students learn in school and the skills they will need upon leaving school. The situation whereby little or no skills are developed has also attracted a barrage of criticisms.

Attempts to assess skills led to changing faces, nomenclature and movements in assessment. There emerged an Education Performance Assessment Advisory Committee in many universities, particularly in the USA National Assessment of Educational Progress (NAEP) also in USA, First International Science Study (FISS), Assessment Performance Unit in United Kingdom, and several other assessment bodies. Several terminologies were also coined, such as alternative assessment, authentic assessment, performance assessment, project-based assessment, and many others. The goals of these assessments were to provide quantitative data on students' performance, particularly in science. A few of these forms of alternative assessments are examined here.

Assessment is changing for many reasons. Changes in the skills and knowledge needed for success, in understanding of how students learn, and in relationships between assessment and instruction necessitates change in 
assessment strategies. The assessment strategies should be tied to the design, content, new outcomes and purposes.

\section{ALTERNATIVES, AUTHENTIC AND PERFORMANCE ASSESSMENTS, WHAT ARE THEY?}

\section{Authentic Assessment}

This is a form of assessment in which students are asked to perform real-world tasks that demonstrate meaningful application of essential knowledge and skills. Other definitions are:

- $\quad$ According to Wiggins (1993), authentic assessment means "engaging in worthwhile tasks and problemsolving activities that demand students' use of acquired/requisite knowledge effectively and creatively". Such tasks are either replicas of or analogous to the kinds of problems faced by adult citizens and consumers or professionals in the field. Also, Stinggins (1987) sees authentic assessment as one that calls upon the examinee to demonstrate specific skills and competencies; that is, to apply skills and knowledge they have mastered.

- "The assessments call upon the examinee to demonstrate specific skills and competencies; that is, to apply the skills and knowledge they have mastered (Stinggins 1987).

Authentic assessment engages students in applying knowledge and skills in the same way they are used in the "real world" outside of school. It is a performance-based assessment that requires a student to go beyond basic recall and demonstrate significant, worthwhile knowledge and understanding through a product, performance, or exhibition. The assessment comprises an authentic task, such as participating in politically-oriented debates, writing for the school newspaper, conducting a research group meeting, or performing scientific research. Students appear to learn best when they see the importance of learning and when the learning environment is familiar to them. Authentic scenarios can provide this environment and relevance to students.

\section{Performance Assessments}

Performance assessment, also known as alternative or authentic assessment (US Ed Dept 1993), is a form of testing that requires students to perform a task rather than select an answer from a ready-made list. For example, a student may be asked to generate scientific hypothesis, solve mathematics problems, converse in a foreign language, or conduct research on an assigned topic (US Education Department 1993). The modes include: open-ended or extended response exercise; extended tasks; and port folios (US Education Department 1993), teacher observation and questioning-further categorized as constructed responses, products and performances (HYPERLINK "http//www.nesu.edu/science junction/index.html"), candidates proficiencies (SMSU 2004), essays, oral presentations, open-ended problems hands-on problem, real world simulation and other authentic tasks (North Central Regional Educational Laboratory 1995). Advocates said that performance assessment may be a more valued indicator of what students know and what he/she is able to do (knowledge \& abilities), that it promotes active learning and curricular-based testing, (Shavelson, Baxter \& Pine 1991), it suggests changes in instructional practice to support effective learning in science (Baxter, Elder and Glaxer 1996), but requires a greater expense of time, planning and thought from students and teachers. Users also need to pay close attention to technical and equity issues to ensure that the assessments are fair to all students.

\section{Alternative Assessment}

Alternative assessment includes any assessment in which students create response to a question-short answer and essay. Musical recitals, theme papers, drama performance, students' posters, art projects and models are other examples and modes (Florida DOE 1996).

It appears that the differences in these various forms of assessment are only in the vocabulary and nomenclature. What is demanded from students and teachers seems not to differ much. An example from a chemistry question on acids, bases and salts might be useful. 


\section{Traditional}

Which of the following is a characteristic of an acid? An acid:

(a) turns red litmus paper into blue

(b) releases hydroxide ions in solution

(c) tastes sour

(d) feels slippery

The correct answer is $\mathrm{C}$.

\section{Alternative}

Differentiate between an acid and a base.

Authentic

Your mother took lime ENO last night for acid indigestion, why? Trace the lime ENO through her system, describing the correct chemical reactions (South East Region Vision for Education 1998).

\section{Performance}

Take $2 \mathrm{~cm}^{3}$ of each of solutions A\&B in separate test tubes. To each, add a drop of litmus solution, write down your observation, and make inferences (WAEC derived).

In all of these examples, the traditional type stands out. It requires the selection of response from given options. This type; i.e. objectively score types of question according to Okebukola (2002), do offer objectivity of scoring, but are woefully inadequate in assessing students' beliefs and in not being intellectually tasking. The others, though, differ in the level of intellectual demands, but students' responses are still written on paper and scored or marked by external assessors or examiners located outside the schools of the students, as is the case in West African Examination Council, WAEC; National Examination Council, NECO; and National Board for Technical Education, NBTE. What is assessed in one word is the product of investigation, as written down on paper by the students. Students could perform tasks correctly and have difficulties in reporting correctly. Students could copy others and pass without performing any task. There are other bandwagon effects, like examination malpractices and false certification. For this and other shortcomings, these types of assessments are open to the same flaws and criticisms as the traditional paper and pencil type.

\section{RECONCEPTUALIST VIEW AND OPTION}

\section{On-the-Spot Assessment and Assessing Written Products of Investigation}

From the ongoing, there is a need for an on-the-spot assessment of skills demonstrated by students. The reconceptualist's view and the option is that the much "-orchestrated" alternative, authentic and performance-based assessments are not strong and precise enough to assess all the skills (science and technological) demonstrated during science activities. There is the need to evolve a more sensitive and imaginative technique to measure sciencelearning outcomes at skill level. The author is advocating for an on-the-spot assessment of skills, especially those skills that cannot directly be assessed through students' written reports of, or products of investigation (see Table 1). 
Table 1: Science and Technological Skills and Appropriate Mode of Assessment

\begin{tabular}{|l|l|}
\hline \multicolumn{1}{|c|}{ Product of Investigation } & \multicolumn{1}{c|}{ On-the-spot assessment } \\
\hline Observing & Observing \\
Inferring & Measuring \\
Interpreting & Selecting appropriate measuring instrument \\
Predicting & Estimating volume and mass \\
Generalizing & Hypothesizing \\
Reporting & Experimenting \\
Communicating & Isolating and controlling variables \\
& Manipulating \\
\hline
\end{tabular}

Examples of skills assessment of a topic in Junior Secondary II \& III Integrated science, adapted from Oloruntegbe (2000) and Oloruntegbe \& Omoifo (2000), will make this point clear, as shown in Table 2.

Table 2: Skills Demonstrated, Mode of Assessment, and Measurement Tools on Topic "Further Investigation of Air" JS II \& III Integrated Science Syllabus

\begin{tabular}{|c|c|c|c|c|}
\hline Task & Skills Covered & $\begin{array}{r}\text { Mod } \\
\text { Product of O }\end{array}$ & $\begin{array}{l}\text { of Assessment } \\
\text {-the-spot Investigation } \\
\text { ssessment }\end{array}$ & Scoring \\
\hline $\begin{array}{l}\text { Light a candle stick provided } \\
\text { and cover with a gas jar, } \\
\text { measure the time it takes for } \\
\text { the candle flame to go out }\end{array}$ & $\begin{array}{l}\text { Ability to: } \\
\text {-perform task correctly } \\
\text {-measure time correctly }\end{array}$ & & $\begin{array}{l}\text {-correct performance } \\
\text {-correct measurement }\end{array}$ & $\begin{array}{l}\text { Checklist } \\
\text { Checklist. }\end{array}$ \\
\hline $\begin{array}{l}\text { Take } 2 \text { candle sticks of equal } \\
\text { length, light them, cover them } \\
\text { separately with } 2 \text { similar gas } \\
\text { jars, take the time it takes for } \\
\text { the flame to go out, record the } \\
\text { observation and make inference }\end{array}$ & $\begin{array}{l}\text { Ability to: } \\
\text {-control variable } \\
\text {-perform the task } \\
\text {-measure time correctly } \\
\text {-observe correctly } \\
\text {-infer correctly }\end{array}$ & $\begin{array}{l}\text {-correct } \\
\text { inference }\end{array}$ & $\begin{array}{l}\text {-controlling variable } \\
\text {-correct performance } \\
\text {-correct measurement } \\
\text {-correct observation }\end{array}$ & $\begin{array}{l}\text { checklist } \\
\text { checklist } \\
\text { checklist } \\
\text { checklist } \\
\text { marking } \\
\text { scheme }\end{array}$ \\
\hline $\begin{array}{l}\text { Again select two candle sticks } \\
\text { of the same length, light the } \\
\text { two at the same time, cover } \\
\text { them separately with gas jars of } \\
\text { different volumes, report your } \\
\text { observation and make } \\
\text { interpretation }\end{array}$ & $\begin{array}{l}\text { Ability to: } \\
\text {-isolate and control variable } \\
\text {-select gas jar of different } \\
\text { volumes } \\
\text {-perform task correctly } \\
\text {-measure time correctly } \\
\text {-observe correctly } \\
\text {-interpret correctly } \\
\text {-report correctly }\end{array}$ & $\begin{array}{l}\text {-correct } \\
\text { observation } \\
\text {-correct } \\
\text { interpretation } \\
\text {-correct } \\
\text { reporting }\end{array}$ & $\begin{array}{l}\text {-isolating \& } \\
\text { controlling variable } \\
\text {-choosing appropriate } \\
\text { apparatus } \\
\text {-correct performance } \\
\text {-correct measurement } \\
\text {-correct observation }\end{array}$ & $\begin{array}{l}\text { checklist } \\
\text { checklist } \\
\text { checklist } \\
\text { checklist } \\
\text { marking } \\
\text { scheme } \\
\text { marking } \\
\text { scheme } \\
\text { marking } \\
\text { scheme }\end{array}$ \\
\hline Calibrate a gas jar to 100 parts & $\begin{array}{l}\text { Ability to: } \\
\text {-perform correctly } \\
\text {-measure correctly }\end{array}$ & & $\begin{array}{l}\text {-correct performance } \\
\text {-correct estimation }\end{array}$ & $\begin{array}{l}\text { checklist } \\
\text { checklist }\end{array}$ \\
\hline $\begin{array}{l}\text { With the trough of water, } \\
\text { calibrated jar, wood block and } \\
\text { candlestick provided, design } \\
\text { and perform experiment to } \\
\text { estimate the volume of air that } \\
\text { support burning, Report your } \\
\text { observation and inference. }\end{array}$ & $\begin{array}{l}\text { Ability to: } \\
\text {-hypothesize } \\
\text {-experiment } \\
\text {-observe correctly } \\
\text {-infer correctly and record } \\
\text { correctly }\end{array}$ & $\begin{array}{l}\text {-correct } \\
\text { observation } \\
\text {-correct } \\
\text { inference and } \\
\text { reporting }\end{array}$ & $\begin{array}{l}\text {-correct hypothesizing } \\
\text {-correct } \\
\text { experimenting } \\
\text {-correct observation }\end{array}$ & $\begin{array}{l}\text { checklist } \\
\text { checklist } \\
\text { checklist } \\
\text { marking } \\
\text { scheme }\end{array}$ \\
\hline
\end{tabular}

Source: Oloruntegbe (2000), Oloruntegbe \& Omoifo (2000) 
The checklist for scoring of skills demonstrated in Table 2 is presented in Table 3.

Table 3: Key to Checklist for Scoring Skills Demonstrated by Students

\begin{tabular}{|l|c|}
\hline \multicolumn{1}{|c|}{ Task performance Score } & Marks Given \\
\hline Ability to perform task correctly without assistant & 3 marks \\
\hline Ability to perform with minor assistance & 2 marks \\
\hline Ability to perform with major assistance & 1 mark \\
\hline Not able to perform at all & 0 mark \\
\hline
\end{tabular}

Source: Oloruntegbe (2000) and Oloruntegbe \& Omoifo (2000)

Oloruntegbe and Omoifo (1999), Oloruntegbe (2000) and Oloruntegbe, and Omoifo (2000, 2008), reported the practicability, suitability and prospect of this type of assessment across variables of gender, ability level and age of students. The major problems and teachers' complaints, as observed by Baxter, et al (1996), are of great cost in terms of time, effort in planning and materials. Education Consumer Guide (1993) remarked that something of worth comes at a price. Laboratory work of O'Neale, et al (1998) is an expensive activity-building, equipping, and training of assessors and technicians. However, the advantages are overwhelming.

\section{CONCLUSION AND RECOMMENDATIONS}

The worth of a school graduate is a product of good teaching and assessing. Superficial effort in this regard will only breed deception and defects students parading high grades from theory and the conventional practical examination without the corresponding skills to go with them. The advantages of on-the-spot assessment, as a complement or supplement of the conventional type, are many and overwhelming. It promotes balance in teaching and assessing. It can signal curriculum reform. It will also make the certificate issued in our school to be of worth and pride. If the school system and education sectors can pay the price, and if the teachers and the students are ready to adopt on-the-spot assessment of skills in addition to assessing products of investigation in science, the practice will enhance the prestige of the system and create a paradigm shift in our science and technological aspirations.

\section{AUTHOR INFORMATION}

Dr K. O. Oloruntegbe is a Visiting Senior Lecturer of Chemistry Education in the Department of Mathematics and Science Education, University of Malya, Kuala Lumpur, Malaysia., He possesses B. Ed, 1983, (Ahmadu Bello University, Zaria), M.Ed 1990; Ph D, 2000, University of Benin, in Chemistry Education. He belongs to the following professional bodies: Science Teachers Association of Nigeria (STAN); National Association of Curriculum Theorists (NACT); National Association of Science Educators and Researchers (NASER); National Association for the Advancement of Knowledge, (NAFAK); and Commonwealth Association for Science, Technology and Mathematics Education, (CASTME). E-mail: ko_oloruntegbe@yahoo.com

\section{REFERENCES}

1. Baxter, G.P; Elder, A.D \& Glaser, R. (1996), Knowledge-based Cognition and Performance Assessment in the Science Classroom, Educational Psychology 31 (2) 133-140

2. Bennet, S.W \& O’ Neale (1998) Skill Development and Practical Work in Chemistry, University Chemistry Education United Kingdom, Milton Keynes, Bucks Department of Chemistry, Open University.

3. Berger, C. F. (1982) Attainments of skills in using science processes: Instrumentation, methodology and analysis. Journal of Research in Science Teaching, 19, 3, 246-260

4. CES National (2002), Overview of Alternative Assessment Approaches Sourced from Fall Forum Workshop given by Excelsior High School.

5. Crist, C; Guill, D. \& Harnes, P. (1998), Purposes of Assessment, Fall Forum Workshop given by Excelsior High School

6. Grant, W. (1990) The Case For Authentic Assessment, Practical Assessment, Research \& Evaluation, 2,2

7. Lake, C; Harmes, P. \& Guill, D. (1998) Defining Assessment, Fall Forum Workshop given by Excelsior High School. 
8. Muella J. (2006), What is Authentic Assessment?, Naperville, IL, North Central College

9. North Central Regional Educational Laboratory (1995), Critical Issues: Rethinking Assessment and its Roles in Supporting Educational Reforms

10. Nwosu, A.A. (1994) Level of acquisition of science process skills among Year One Senior Secondary School students. Journal of the Science Teachers Association of Nigeria, 29, 1\&2, 47-53

11. Ogunleye, A.O. (1996), Level of acquisition of process skills among some physics students and implication for science education. Journal of the Science Teachers Association of Nigeria, 31, 1\&2, 39-46

12. Okebukola, P. (2002) Beyond the Stereotype to New Trajectories in Science Teaching, Text of Special Lecture Presented at the $43^{\text {rd }}$ Annual Conference of the Science Teachers Association of Nigeria (STAN) and Commonwealth Association of Science, Technology and Mathematics Educators (CASTME)

13. Oloruntegbe, K.O.(2000) Effect of Teachers' Sensitization on Students' Acquisition of Science Process Skills and Attitudes, Unpublished Ph.D Thesis of Faculty of Education, University of Benin

14. Oloruntegbe, K.O. \& Omoifo, C.N. (2008). Differences in Students' Attainment in Skills Assessed On-theSpot and Through Products of Investigation. Journal of Research in Curriculum and Teaching. 2 (1)

15. Oloruntegbe, K.O. \& Omoifo C.N. (2000) Assessing Process Skills in STM Education: Going Beyond Paper and Pencil Tests, Educational Thought, 1(1) 35-44

16. Omoifo C.N. \& Oloruntegbe, K.O. (!999) On-the Spot Assessment: An Additive to Paper and Pencil Test Technique for Assessing Science Process Skills, 40rh Annual Conference Proceeding of the Science Teachers Association of Nigeria. Pages 41-47

17. Shavelson, R.J; Baxter, G. P \& Pine, J. (1999), Performance Assessment in Science, Applied Measurement in Education, 4 (4) 347-362

18. Southwest Minnesota State University (2004) Educational Performance Assessment System, Communities for Investigating Learning and Teaching, Marshall MN 56,258

19. Tyler, R.W. (1049), Basic Principle and Curriculum and Instruction, USA, Chicago, University of Chicago Press

20. US Department of Education (1993) Performance Assessment, in Zimmermann, J. (Editor) Consumer Guide, Office of Educational Research and improvement, 2 